\title{
Role of e-Governance to strengthen higher education system in India
}

\author{
Dr. R. K. Shrivastava, Dr. A.K. Raizada, Mrs. Neeta Saxena \\ Professor, S.M.S.Model Science College, Gwalior \\ Principal, Gautam B.Ed.college, Dabra. \\ Assistant Prof.ITM, Gwalior
}

\begin{abstract}
A good higher education system is required for overall development of a nation. A remarkable growth in the higher education sector had made the administration of higher education institutions intricate. Many researches reveal that the integration of ICT helps to reduce the intricacy and enhance the overall administration of higher education. Electronic Governance (e-Governance) is the use of Information and Communication Technologies (ICT) for the planning, implementation, and monitoring of government programs, projects, and activities. E-Governance is expected to help deliver cost-effective and easy-to-access citizen services, and improve processing of transactions both within the government, and between the government and other agencies. E-Governance is understood as a set of activities involving the effective contribution of information and communication technology (ICT) for strengthening administration and management in higher education system in India has declined somewhat over the past three decades due to remarkable increase in the number of colleges and universities and their privatization. It has become very important for the government to keep track of their functioning. Educational institutions may have various requirements that include computerization and management of processes such as registration, admission, student information, classes, time table, transport, attendance, library, salary and expenses, examinations, performance, grades, hostels, security and reports. Many of the software providers allow their clients to choose from the available modules to suit their needs to monitoring of these aspects. In this study, an attempt has been made to discuss the concept of E-Governance and use of latest application in higher education sector.
\end{abstract}

Key Words: E-Governance, Information and Communication Technologies (ICT), Indian higher education system (IHS), IMS (Management Information System)

\section{Introduction:}

E-Government can transform citizen service, provide access to information to empower citizens, enable their participation in government and enhance citizen economic and social opportunities, so that they can make better lives, for themselves and for the next generation. Formation communication transactions, integration of various stand-alone systems and services between Government-to-Citizens (G2C), Government-toBusiness(G2B), Government-to-Government ( G2G) as well as back office processes and interactions within the entire government frame work. Through the e-Governance, the government services will be made available to the citizens in a convenient, efficient and transparent manner. The three main target groups that can be distinguished in governance concepts are Government, citizens and businesses/interest groups. In e-Governance there are no distinct boundaries. Generally four basic models are available-Government to Customer (Citizen), Government to Employees, Government to Government and Government to Business. Governments are specialized institutions that contribute to governance. Representative governments seek and receive citizen support, but they also need the active cooperation of their public servants. Governance is the outcome of politics. [9]

Change has been happening at an uneven pace in anygrowth-oriented industry, and the education sector is noexception. Rapid growth in the field of education has made governance in academic sector a very complex task. The $21^{\text {st }}$ century has witnessed tremendous advancements in technology which has led to far-reaching developments in the administrative system. Cost-effective technology combined with the flexibility in learning and administrative activities is essential to enhance efficiency. Computers can be used extensively for educational administration. There are some of the areas where computers can be used for effective educational administration (Ben-Zion Barta et. al. 1995):

- General Administration

- Pay Roll and Financial Accounting

- Administration of Student Data

- Inventory Management

- Personnel Records Maintenance

- Library System 
Information and Communication Technology (ICT) plays a vital role in supporting powerful, efficient management and administration in education sector. It is specified that technology can be used right from student administration to various resource administration in an education institution (Christiana Maki 2008). Sharad Sinha (2008) mentioned the various administrative challenges for Indian education system of the 21st century as given below:

- Global and local challenges

- Universal and individual challenges

- Competition and equity challenges

- Extraordinary expansion of knowledge

Moreover many studies revealed the need for ICT integration into administrative activities of higher education institutions. The various ways of introducing technology in education institution administration are the following (Caroline Salerno 2009):

- $\quad$ Sending e-mail notices and agendas to staff, rather than printing and distributing them

- Submission of lesson plans through e-mail

- Foster technology growth by asking parents to write e-mail addresses on medical forms.

- Insist that all teachers create a class Web page

- Attend technology conferences to see what other schools are doing, what other teachers are doing to integrate technology, and what principals are doing to encourage the use of technology in their schools and classrooms.

- Admissions through web-enabled services.

- All day-to-day activities of the institution (General Administration)

- Staff administration

- $\quad$ Single Window System for students.[2]

\section{Role of higher education in Society:}

Higher education is generally understood to cover teaching, research and extension. If critically analyze the different concept of higher education it can list the various roles higher education plays in the society. Higher education is the source or feeder system in all walks of life and therefore supplies the much-needed human resources in management, planning, design, teaching, and research. Scientific and technological advancement and economic growth of a country are as dependent on the higher education system as they are on the working class. Development of indigenous technology and capabilities in agriculture, food security and other industrial areas are possible because of our world- class higher education infrastructure. Higher education also provides opportunities for lifelong learning, allowing people to upgrade their knowledge and skills from timeto time based on the societal needs. The Kothari commission (1996) listed the following roles of the universities(Higher education institutions in the modern Society):

(i) To seek and cultivate new knowledge, to engage dynamically and fearlessly in the pursuit of truth, and to interpret old knowledge and benefits in the light of new needs and discoveries.

(ii) To provide the right kind of leadership in all walk of life, to identify gifted youth and help them develop their potential to the full of cultivating physical fitness, developing the powers of the mind and cultivating right interests, attitudes and moral and intellectual values.

(iii) To provide the society with competent men and women trained in agriculture, art, medicine, science and technology and various other professions who will also be cultivated individuals, imbibed with a sense of social purpose.

(iv) To strive to promote quality and social justice and to reduce social and culture differences through diffusion of education

(v) To foster in the teachers, students and through them in the society generally, the attitudes and the values needed for developing the good life in individuals and society(GOI, 1996)

\section{E-Governance in Higher Education}

India has one of the largest higher education systems in the world .Despite having the largest higher education system, the quality of education, in general, cannot be claimed to be the best. Technical and vocational Education in India has seen enormous growth in recent years with a large increase in total number of institutes imparting higher education. On one hand, this growth promises to produce more skilled youth to fulfill needs of ever growing Indian industry and on the other hand it poses a huge challenge for the governing bodies like UGC, AICTE, NCVT, NCTE, PCI, MCI, INC, DCI etc and state technical education boards to maintain \& improve the quality of education being imparted through these new \& existing technical and Vocational institutes. But as has been reported by NASSCOM(National Association of Software and Service Companies) in its 2004 report, out of 3 million graduates and post-graduates added to the workforce in India every year only $25 \%$ of technical and 10- $15 \%$ of non-technical graduates are employable by growing IT, and other sector, 
points to is a very serious situation. This lack of knowledge, qualities \& skills desired by the employers, from the youth, may lead to the problems like unemployment/underemployment, which detain will lead to their disapproval\& hence their offense that will be reflected in terms of an increase in crime and other antisocial activities.[4]

Now a days, our education system is untidy, to say the least. It is characterized by substandard technical and vocational institutions lagging good infrastructure and qualified teachers, teacher truancy, obsolete syllabi, inadequate infrastructure, unemployable graduates and a lot more other problems. The scenario has been further worsened due lack of some effective \& real time monitoring mechanism \& widespread corruption prevalent in Govt. regulatory bodies that help such substandard institute to start \& remain functional without bothering to maintain any quality at all. Mushrooming of a large number of unrecognized \& substandard fake universities/institutions distribution fake technical certificates, diplomas, degrees \&Ph.Ds, fraudulently, without being caught, is also another outcome of such a untidy system. [5]

\section{Necessity of e- Governance in Higher Education:}

If the quality of our higher education system has to be improved to make these institutes really word class, then there is no alternative to the introduction of e-governance in this sphere at the fastest possible pace. Implementation of e-governance in technical and vocational institutes will enable their effective \& real time monitoring by Government/the regulatory bodied \& other stakeholders their own managements, parents of the students \& the society, thereby forcing them to maintain quality \& become more responsible. E-governance process brings transparency in the system, so e-governance initiatives in the field of higher education will help reduce the corruption up to a large extent. The introduction of e-governance in higher education is one such concept that can empower the governing bodies to administer the progress of the education plan in the whole country and serves various stakeholders in a much better ways. E-Governance is becoming a global phenomenon that is increasingly attracting the attention of community citizens including politicians, economists, decision and policy makers amongst others (Naheed et al., 2009).

According Info Dev Report (2002) an effective e-governance satisfies these following needs:

- Providing greater access to government information;

- Promoting public engagement by enabling the public to interact with government officials;

- Making government more accountable by making its operations more obvious and thus reducing the opportunities for corruption; and

- Providing development opportunities, especially benefiting rural and traditionally underserved communities.

E-Governance in higher education system will enable various stakeholders to control the improved operational efficiency in various key processes like grants, utilization certificates, approval processes, feedback mechanism etc. With deeper visibility and increased operational efficiency the Indian higher education system (IHS) would be implemented not only to satisfy the needs of students by making them more employable but also combat possible competition from foreign universities.

In order to remove the copying of procedures, there should be consolidated information about each university and college to track their performance. The tools of e-governance may enable the universities or colleges to submit the documents online for approval. All agencies should internally co-ordinate to carry the details from common pool. This would greatly reduce the unnecessary duplication of work in the university. Apart from this there may be a number of other services that can be provided with the introduction of such type of governance.[1]

\section{Models of Private Sector Participation in Higher Education:}

Recently, the University Grants Commission (UGC) has recommended four models of Public Private Partnership to the Planning Commission and according to an estimate; the country requires an investment of over US $\$ 150$ billion in the next 10 years. The four models proposed by the Planning Commission are in terms of basic infrastructure model. [10]

- Basic Infrastructure Model: The private sector invests in infrastructure and the government runs the operations and management of the institutions in turn, making annualized payments to the private investor.

- Outsourcing Model: Private sector invests in infrastructure and runs operations and management and the responsibility of the government is to pay the private investor for the specified services.

- Equity/Hybrid Model: Investment in infrastructure is shared between government and private sector while operation and management is vested with the private sector.

- Reverse Outsourcing Model: Government invests in infrastructure and the private sector takes the responsibility of operation and management.

Colleges and universities will need to change radically in the coming years and first think social intranets may be a key to this transformation. 


\section{Benefits of e-Governance in Higher Education:}

The benefits of e-governance in an educational sector are improved efficiency, increase in transparency and accountability of educational administrative activities convenient and faster access to services, and lower costs for administrative services. The multi-faceted benefits of e-governance can be described as under these points [7]:

- Benefit to university

(i) Centralized information access from anywhere

(ii) Increase in student enrollment ratio.

(iii) Provide quality e-services, e-participation,

(iv) Increase clearness

(v) inventive teaching tools

(vi) Improved decision making, Private Public Participation

(vii) less paper work

- Benefits to students

(i) Increase participation in education affairs

(ii) Personalized login for each students

(iii) extensive saving in time cost \& efforts

(iv) Information \& transaction services

(v) Job opportunities

(vi) Social connectivity for collaboration

(vii) Students can access virtual lectures \&Seminars.

(viii) Students can solve their problems like- examination queries, result verification etc.

(ix) Students can submit feedback to university.

- Benefits to colleges

(i) Data can access easily

(ii) Electronic data exchange with university

(iii) Saving of hidden operational cost

(iv) Instant statistical report generation

(v) Helpful for NAAC accreditation

- Overall education system

(i) Long term impact on organization goals

(ii) Improve education system

(iii) Empowerment of faculties, students \& encouragement of their participation in governance.

Suggestions and Recommendations:

The online methods enable more effective education and offer significant advantages over traditional services.[7]

Provide E Services - After the implementation e-governance, we improve the delivery of services to students, faculty by providing services like enrollment, examination, result, feedback, requests for documents, requests for certificates, issuing admit cards and ID cards, employment etc.. The system provide timely alert to colleges through SMS /Emails. E-governance in education provides new ways of communicating to the students, imparting education and organizing and delivering information and services.

Improved education system - E-governance in education sectors allows use of information and communication technologies with the aim of improving education, improve information, service delivery, encourage student participation in the decision making process, making administration transparent and effective and give universities a new channel of educational unemployment. Also, the system can obtain feedback from industry and students to modify course curriculum if deemed appropriate by the authorities. This will allow all the lesser performing colleges to reduce the gap with better performing institutes. It will be help in the betterment of the higher education in the country and increase the number of employable students.

Innovative Teaching Tools - The new technologies offer vast opportunities for progress in all walks of life with the introduction of new technological initiatives the structure of higher educational institutions has changed. The changing role of lecturers, the changeable learning environment and the design of e-Learning facilities all contribute to a potentially more flexible organizational structure of higher education in rural area. The future delivery of education will be based through eLearning technology providing lecturers with superior teaching tools. The online methods enable more effective education and offer significant advantages over traditional teaching methods. This has been possible by technological implementation based environments such as bulletin 
boards, virtual lectures and e Libraries and video conferencing. In e learning environment can support communication with classmates and lecturers.

Private Public Participation - almost all e-government project have found it convenient to involve different private agencies for different tasks through public-private-partnership (PPP) arrangements. These tasks include design and development of application software, population of data and content in the regional language, procurement and installation of networking and computer systems, deployment of software and delivery of services.

Centralized Information - E-Governance has provided electronic information infrastructure to simplify service delivery, reduce duplication, and improve the level and speed of service at a lower cost. The centralized information approach of e-Governance keeps all information at one place in electronic form. This approach of making information secure prevents it against any theft or leakage.

Use of intranet - Intranet-based training provides a low cost and knock-on savings, is that it can be a virtual twoway system, with students connected to mentors and teachers receiving real-time feedback and support. Managers with employees scattered among sites and locations, particularly if they are so far flung that they are in different areas, need a cheap and effective way to communicate them. ICT is already proven as the way to access knowledge based information from anywhere to anytime but a limitation of the university that they can't communicate with other colleges.

With the help of above benefits and suggestions it is possible to design a system that is student centric and can provide a variety of services - informative, interactive, and transactional and integrated system across the entire spectrum of the education sector. Central Universities, State Universities, Autonomous Institute, Deemed and Private universities and affiliated colleges will enter the data and caters the need of MIS of regulating and coordinating bodies.

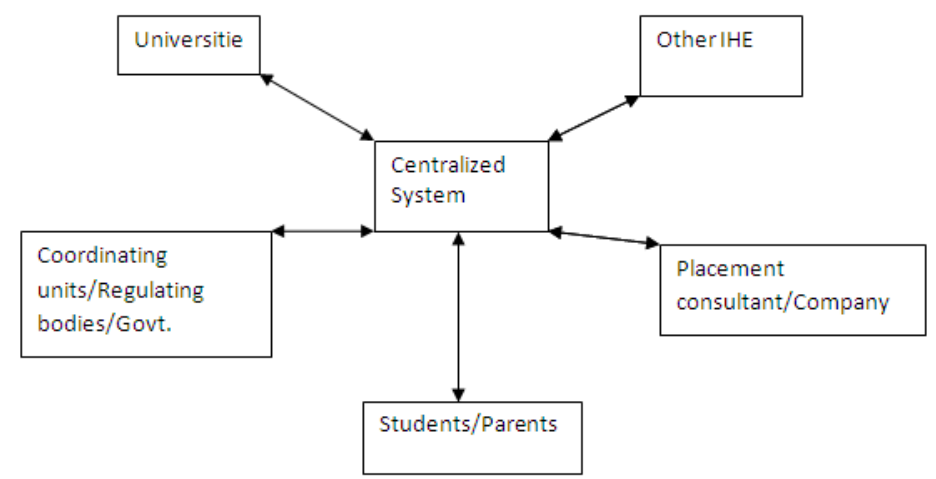

Fig: Use of e-governance in Higher Education

Users can tap the system and find out the related information needed. The higher education coordinating and regulating bodies could obtain the reports on various issues about future planning like budget, demand of courses etc. The regulatory body has a critical role to play according to this model. These units will be responsible of data integration and will cater the need of various stakeholders. Following are the main activities required in this process. The MIS working at this level in the model will provide the following information to the regulating and accreditation bodies.

\section{Conclusion:}

The planning for efficient administration of higher educational institutions, increasing Global communication skill, to achieve the world class standard it is necessary to have a improved collaboration and access to information available in all the parts of the world are possible only by introducing IT in Educational Sector with e-governance as a security for maintaining standard. The e-governance needs security for smooth information flow, best practice database and enhanced capacity for information analysis etc. Government should support by enacting favorable legislations and updated amendments for maintaining standards in the educational process and improvements in the related field. It requires completely new infrastructure, procedures, policies and working skills for producing and collecting online information. With the advent of ICT, electronic governance is an emerging trend to re-invent the way the government works, becoming a new model of governance. Such a comprehensive and integrated system can also enable authorities to analyze the performance 
of one of the best performing institutes and compare it with other schools and colleges to identify the gaps. Through e-governance we improve the quality of higher education system in India. E-governance can create the transparency between the universities, colleges and students. It will bring forth, new concepts of governance, both in terms of needs and responsibilities. Many problems of higher education system can be solved by the Public Private Partnership model and e-governance.

\section{References:}

[1]. Ashok Kumar (GIAN JYOTI E-JOURNAL, Volume 1, Issue 2, Jan - Mar 2012) E-Governance in Education Sector

[2]. Dr.R.Krishnaveni and J.Meenakumari(International Journal of Environmental Science and Development, Vol. 1, No. 3, August 2010)Usage of ICT for Information Administration inHigher education Institutions - A study

[3]. HarshitaBhatnagar.( International Journal of Scientific \& Engineering Research, Volume 4, Issue 5, May-2013) e-Governance in Higher Education: A Case Study of IGNOU, New Delhi.

[4]. JatinderGarg, SonuBalaGarg and NavdeepChoudhary (Research Cell: An International Journal of Engineering Sciences. Issue Sept 2011, Vol. 4) Effective Implementation of E-Governance in Technical Institutions in India using ICT to Make them World Class.

[5]. Mr. Sanjeet Kumar Tiwari, Mr. JubrajKhamari, Anjali Singh.(IOSR Journal of Research \& Method in Education. Volume 2, Issue 3, Jul. -Aug. 2013) Promoting E- Governance Culture in Higher Education Institutions.

[6]. Prateek Bhanti1, Dr. S. Lehri2, Dr. NarendraKumar(International Journal of Emerging Technology and Advanced Engineering. Volume 2, Issue 8, August 2012))E-Governance: An Approach towards the Integration of Higher Education System in India.

[7]. RanjeetaKapoor and NishthaKelkar(National Conference on New Horizons in IT - NCNHIT 2013) E-Governance: Higher Education in Rural Area.

[8]. SebahatBartınOrmanFakültesiPeyzajMimarlığıBölümü 2007(Importance of e-education and e-governance: Case of zonguldakkaraelmas university,Department of Landscape Architecture)

[9]. SudipSuklabaidya, AngshuMaanSen(International Journal of Emerging Trends \& Technology in Computer Science. Volume 2, Issue 3, May - June 2013)Challenges and Prospects of E-governance in Education.

[10]. Report of the Working group on Higher Education for the XII Five Year Plan. September 2011 